\title{
GEOLOGY OF EUROPE: A SYNTHESIS
}

by

Jean Aubouin

Europe is a "continental crossroads" rather than a continent in itself: crossroads of orogenies, crossroads of oceanic openings, crossroads of climates, it exemplifies in rather limited space, all the geological problems that arise on a continental scale. In this article, the President of the 26th International Geological Congress traces Europe's complex geological history and accounts for some of its ambiguities.

Two oceans - the Atlantic and the Arctic - bound Europe on the west and north with broad continental shelves. Its eastern and southern boundaries are somewhat more varied. The Urals to the east, a Hercynian chain, welded the North Atlantic continent to Asia in the Permian and established Eurasia, which was to define its identity after the opening of the Tethys in the Triassic and Jurassic, and later the Atlantic in the Cretaceous and Tertiary. The Lesser Caucasus, an Alpine chain to the south, developed on the southern margin of Eurasia and represent the northern branch of the Alpine orogen. (The Greater Causasus are generally considered as part of Europe, even though they represent the true mountain barrier.)

Intramontane seas formed in the final phases of the Alpine orogeny - the Caspian, Black and Aegean Seas, as well as the Mediterranean. The Straits of Gibraltar were formed in their present position in the Pliocence, as were both the Aegean Sea and the Sea of Marmara which fix the alignment of the Dardanelles and the Bosphorus.

The Hercynian orogeny played a key role in defining Europe as such, since it led to the formation of Eurasia. Before that, the history of Europe was that of "Euramerica": the Caledonian and Hercynian chains of western Europe continued naturally into Greenland and North America. Later on in the Alpine orogeny, "Eurafrica" predominated, the North African chains having an obvious kinship to the Alpine chains of Mediterranean Europe.

\section{Tectonics of Europe}

Four tectonic ensembles, each defined by a corresponding orogeny, subdivide Europe: Precambrian Europe is considered as a whole, for its chronological divisions do not form distinct natural regions; the others are Caledonian or northwest Europe, Hercynian (Variscan) or southwest Europe, and Alpine or Mediterranean Europe (Fig. 1). Central Europe developed at the crossroads of these different orogenies.

\section{Precambrian Europe}

The Precambrian forms three complexes in Europe: the shields in which the Precambrian crops out, undeformed through the whole of Phanerozoic time; the nuclei, caught up in later orogenies; and the Russian platform, where a horizontal Phanerozoic cover rests with little or no deformation on a permanently stable Precambrian basement.

The shields include the Baltic Shield (or Fennoscandia) which forms the greater part of Sweden, Finland and the Russian border area, including the floor of the Barents Sea; the Ukrainian Shield, which crops out southwest of the Russian Platform (of which it forms the foundation); and the Hebridean Shield (or Eria) in the northern part of the British Isles, which may also be considered as a nucleus caught up in the Caledonian orogeny.

The shields are characterized by their relatively great antiquity: their metamorphic rocks are older than $1500 \mathrm{Ma}$ and covered by detrital red beds of late Proterozoic age.

Precambrian nuclei are found in the younger Caledonian and Hercynian chains, especially along the axis of the central European cordillera: the Armorican Massif, Massif Central, Vosges, Black Forest and Bohemia, and in the axis of the Iberian meseta. In the Alpine chain, they are on the axis of the Dinaride-Balkan complex - the Serbo-Macedonian and Rhodope massifs.

If younger Precambrian material is found in these nuclei (as

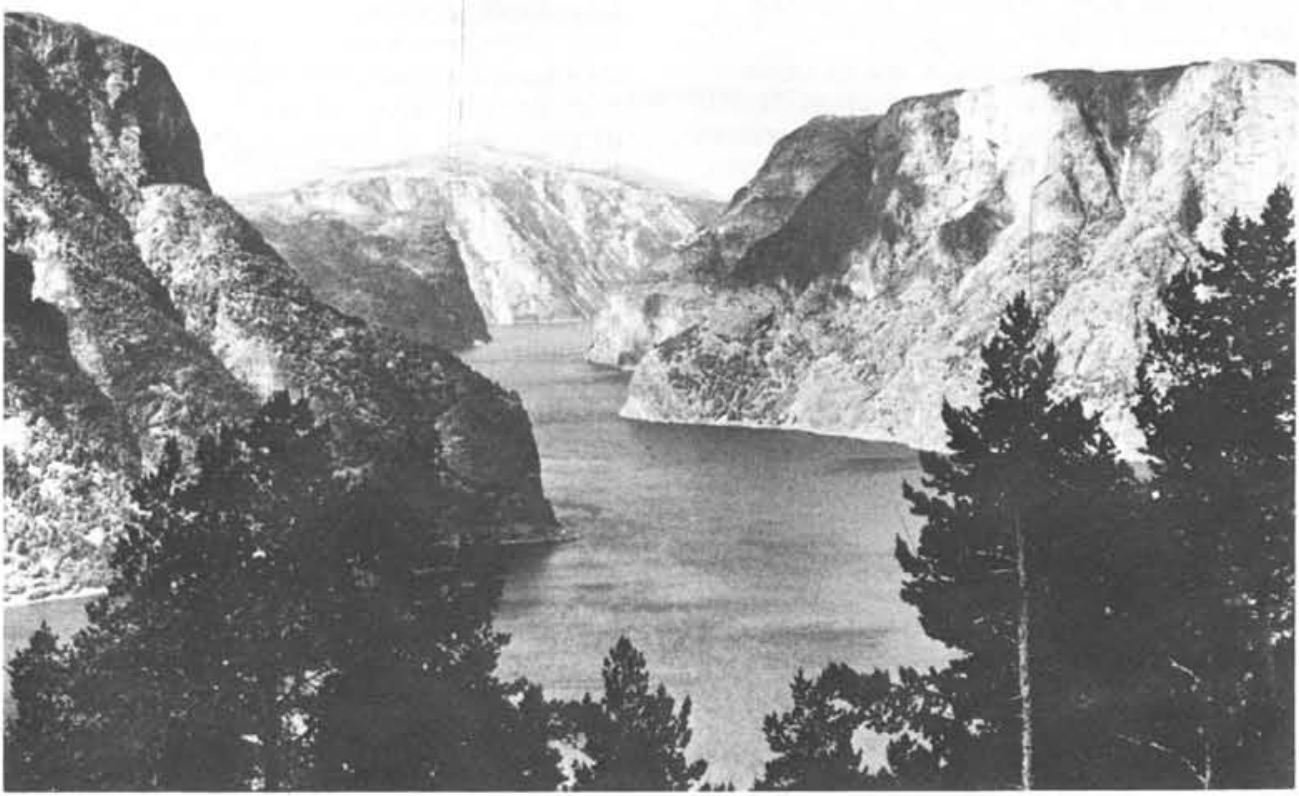

" $U$ " shaped valley of Aurlandsfjord, from above Aurlands, West Norway: Precambrian crystallines of the Caledonian Upper Jotun Nappe. (Photo courtesy National Museum of Wales) 


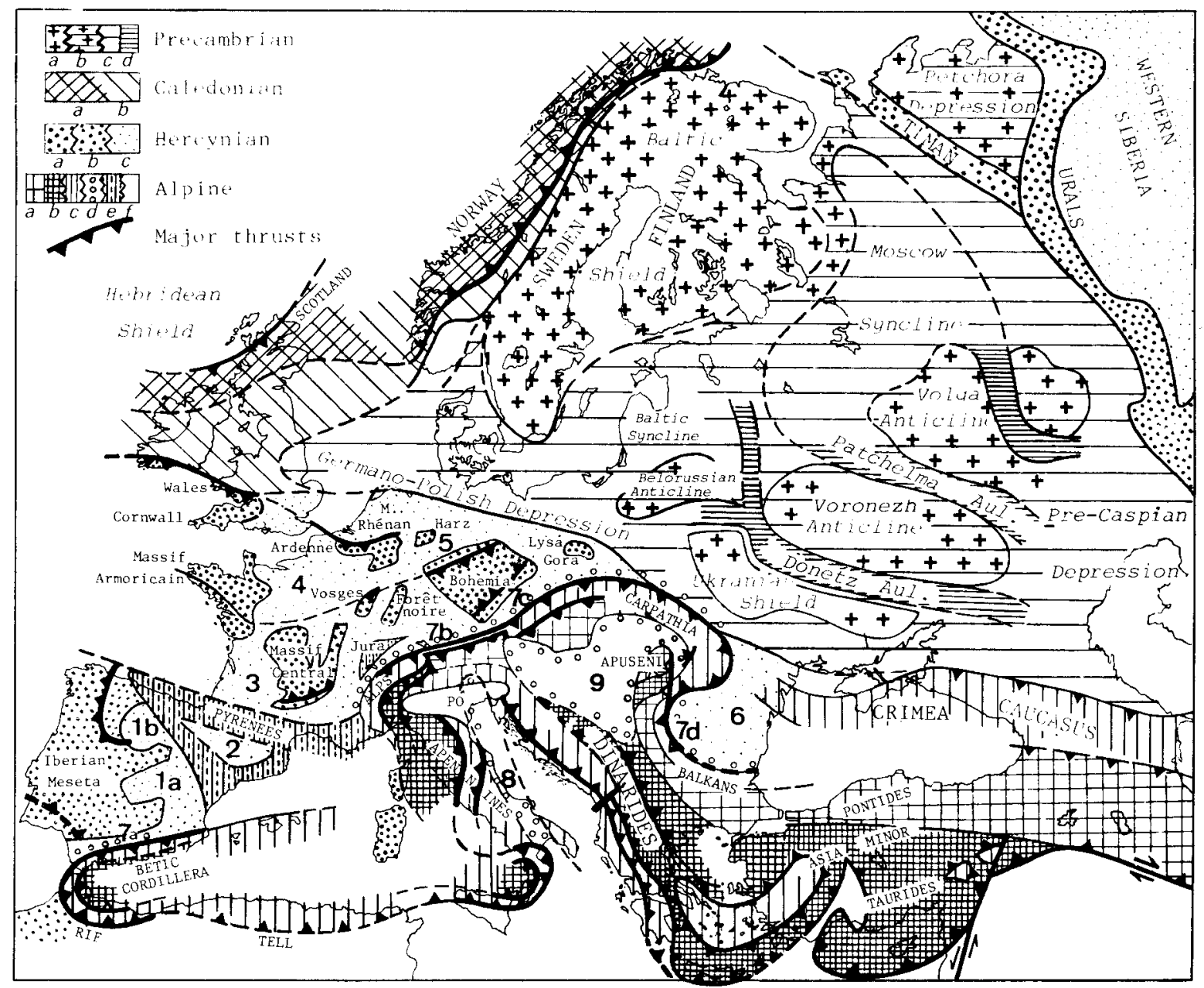

Figure 1. Structural Outline of Europe: Precambrian: a) Shields, b) Anteclises; Uplifted areas of continental platform, c) Syneclises; Depressed areas of continental platform, d) Aulacogen. Caledonian: a) Internal metamorphic zones and/or ophiolites, b) External weakly metamorphosed zones. Hercynian: a) Internal metamorphic zones, b) External zones, c) Hercynian platform. Alpine: a) Internal zones in general, b) Internal metamorphic zones and/or ophiolites, c) External zones, d) Molasse, e) Intracontinental Mountain Chains, f) Pliocene-Quaternary. 1 Castillian Basins (1a - Nouvelle Castille, $1 b$ - Vieille Castille), 2 Ebre Basin, 3 Aquitaine Basin, 4 Anglo-Paris Basin, 5 Assemblage of German Basins, 6 Dacique Basin, 7 Alpine foredeep (7a-Guadalquivir, 7b-Alpine foredeep proper, $7 c$ - Peri-Carpathic foredeep, $7 d$ - Balkan foredeep) 8 ItaloDinaric foredeep, 9 Pannonique Basin (backdeep).

in the Pentevrian of northern Brittany and the Channel Islands), it consists chiefly of late Precambrian formed in marine environments around the periphery of the Precambrian shields. In many cases the rocks are of oceanic facies (radiolarite and flysch) and the oceanic crust itself may be represented by ophiolites. (The Brioverian of western Europe, a regional equivalent of the Rhiphean of Asia, serves as an example.)

These areas were affected at the end of the Precambrian by an orogeny called the Cadomian of western Europe - the equivalent of the Panafrican orogeny which developed in Africa and South America, the Baikalian in Asia and, in a more general way, the Assyntic orogeny as well. The Cadomian orogeny was accompanied and/or followed by an early Cambrian glaciation of which tillites, in the form of moraines, are found around the Scandinavian Shield or as redeposited marine sediments in the Armorican Massif.

The Russian Platform is overlain by formations that have remained horizontal since the Cambrian. Their deformation is on the thousand-kilometre scale, whether anticlinal (as the anteclises of Byelorussia, Voronezh and the Volga) or synclinal (the Baltic and Moscow syneclises), or in the form of troughs (the aulacogens of Donetz and Patchelma). On its southern border, the platform is fringed by a marginal depression which is more pronounced to the southwest and southeast (the Germano-Polish and Pre-Caspian depressions); Permian saliferous deposits are abundant in both, and give EPISODES, Vol. 1980, No. 1 rise to numerous salt domes.

\section{Caledonian Europe}

The Caledonian of Europe manifests itself in Scandinavia (Norway, the Swedish borders and Spitzbergen) and in most of the British Isles except for the southernmost part. It originated in a Caledonian geosyncline to the west of the Baltic Shield; its oceanic crust formed Caledonian ophiolitic nappes.

The Caledonian chain is a typical collision chain of opposing vergences, one side directed toward the Baltic Shield (Spitzbergen, Scandinavia, British Isles), the other toward the Canadian Shield or Laurentia (East Greenland). The natural continuation of this structure is in Canada (Newfoundland, Maritime Provinces, southern Québec) and nor theastern United States (Allegheny Mountains). Nappes form a prominent feature in Scandinavia and the British Isles, constituting some of the earliest nappe complexes in the world to have been described (by Geikie in Scotland and by Tornebohm in Scandinavia).

Identification of the Caledonian orogeny in the rest of Europe is difficult because it has been caught up in the Hercynian and Alpine orogenies. The nature of the problem varies: it is a stratigraphical issue where the Devonian rests unconformably on formations once thought to be Precambrian (Brioverian), but which are now known in many cases to be of Lower Palaeozoic age (as with the Armorican Massif, especially in the Vendee). It is a chronological problem for 
granites once thought to be Hercynian, Dut wnicn now appear to be Caledonian according to radiometric determinations (as, for example, in the Massif Central). It is a tectonic problem where the Ardennes deformation, lying to the south of the Russian Platform and its continuation, reveals structures with a northward vergence, implying that the Ardennes Caledonian represented only the margin of the chain, while the main part lay to the south.

\section{Hercynian (Variscan) Europe}

The Hercynian is represented in most of the ancient massifs of central and western Europe which are separated from one another by Mesozoic and Tertiary sedimentary basins, or by Tertiary troughs linked with the Alpine orogeny. Thus, while the structure of Caledonian Europe is obvious, that of the Hercynian must be reconstructed in the mind.

One could say that Hercynian Europe consists of two chains with opposing vergence. The central European cordillera, extending from southern Britain through France, Germany and Czechoslovakia, lies on the edge of the north Atlantic continent; the latter forms its foreland and is separated trom it by a molassic foredeep in which the Coal Measures of Middle Carboniferous age were deposited. The cordillera has a Precambrian axis which was metamorphosed and granitized during the Hercynian cycle; it extends from southern Brittany through the Massif Central, Vosges, the Black Forest to Bohemia.

In the north it displays structures that are overturned or thrust northward (the Condroz nappes of the Harz, and the Sudeten Mountains); to the south, the structures are thrust southward (the Montagne Noire and Cevennes nappes of the Massif Centrak; the Moravian nappes of southeastern Bohemia). The "Faille du Midi" of the Franco-Belgian coal basin (the continuation of the Condroz thrust), together with examples from the Alps and Provence, helped Marcel Bertrand to define the concept of overthrusting. The Pyrenees are part of the southern Hercynian domain of the central European cordillera as far as the coal basin of Asturia. This represents the common foredeep of the cordillera and the one that forms the Iberian meseta.

The metamorphosed and granitized core-zone of the Iberian (or Hesperic) cordillera lies nor theast of the Iberian meseta and extends from NW to SE. Structures are overturned toward the northeast in the north and toward the southeast in the south.

Considering that Hercynian structures in northwestern Spain describe a Cantabrian curve around the common foredeep of Asturia, and that the Iberian peninsula has undergone displacement to the east accompanied by a southward rotation (thus opening the Bay of Biscay), it is possible that the central European and Hesperic cordilleras once formed a single edifice.

Hercynian Europe was built up in successive phases: the Breton phase (Devonian to Lower Carboniferous), the Sudeten phase (Lower to Middle Carboniferous), the Asturian phase (Middle to Upper Carboniferous), and the Saalian phase (end of Carboniferous). A Palatine phase (Permian to Triassic) is added by some authorities, but it is marked only by the transgression of Triassic deposits over warped and faulted Permian; it constitutes, however, an important phase in the Urals.

Taken together, the first three phases built the main Hercynian structures, whose distribution is common in both the central European and Hesperic cordilleras. The oldest of these - the Breton phase - affected mainly the axes of chains, while the Asturian (the latest) deformed their margins. The Saalian phase corresponds to the late deformation of the Upper Carboniferous intramontane coal basins; this deformation followed the major Hercynian movements.

The Palatine phase is not, strictly speaking, part of the Hercynian. The structural framework of the Permian, with its horst-graben structures and slides, is a harbinger of Alpine Europe. It probably represents the first movements

EPISODES, Vol. 1980, No. 1 associated with the opening or the letnys. In later times it continued to control a certain number of the essential tectonic features of Europe, though not always the ones that are most obvious among Alpine structures. The importance of the late Hercynian contribution to the structure of Europe may well be greater than is generally believed.

The extension of the Hercynian orogeny through the rest of Europe takes two forms:

(i) beyond the Hercynian front and in the North Atlantic foreland, a Perihercynian fault field is characterized by a system of horsts and graben best displayed in the Midland Valley of Scotland and its continuation in Ireland, but also found on the other side of the Atlantic - in Newfoundland and Nova Scotia;

(ii) Hercynian deformations are found in the roots of the Alpine chains, including the Pyrenees-Provence complex, throughout the Alpidic branch, and in North Africa.

\section{Alpine Europe}

The European Alpine cycle falls into two successive phases: first, the opening of the Tethys from Triassic to Jurassic created the Alpine "geosyncline"; later, the opening of the Atlantic from Cretaceous to Tertiary led to the closing of the Tethys and the formation of Alpine chains. The continent of Europe was subjected to transgressions from two seas - the Tethys and a boreal sea - until the formation of the Atlantic.

There was thus, in both mountain chains and basins, a preAtlantic and an Atlantic period. In southern Europe, especially in the Alpine chains, the change from one to the other is at the Jurassic-Cretaceous boundary, while in northern Europe it is even as late as Palaeogene. The end of the Jurassic, however, is an important phase everywhere.

\section{Principal Alpine Complex}

The Alpine chains of Europe form two basic complexes. The principal one is linked to the collision of Europe and Africa which closed the Tethys. This complex has opposing vergences: an Alpidic branch on the margin of the European continent and with vergence toward it, runs from Gibraltar to Asia Minor by way of the Betic Cordilleras, the Alps, the Carpathian arc and the Balkans; a Dinaric branch on the margin of the African continent, with vergence toward it, runs from Gibraltar to Asia Minor by way of the North African chains, the Appennines, the Dinarides and the Aegean arc.

The Dinaric branch is strongly folded back on itself in the Italo-Dinaric zone, which is moulded onto a spur of Africa (the Adriatic or Apulian spur, named after the stable platform of southern Italy). Recent Mediterranean history has left this part of Africa isolated on the southern flank of Europe.

The ophiolitic suture, obscure in the northern Mediterranean, becomes clearer in southern Italy (Calabria) and can be

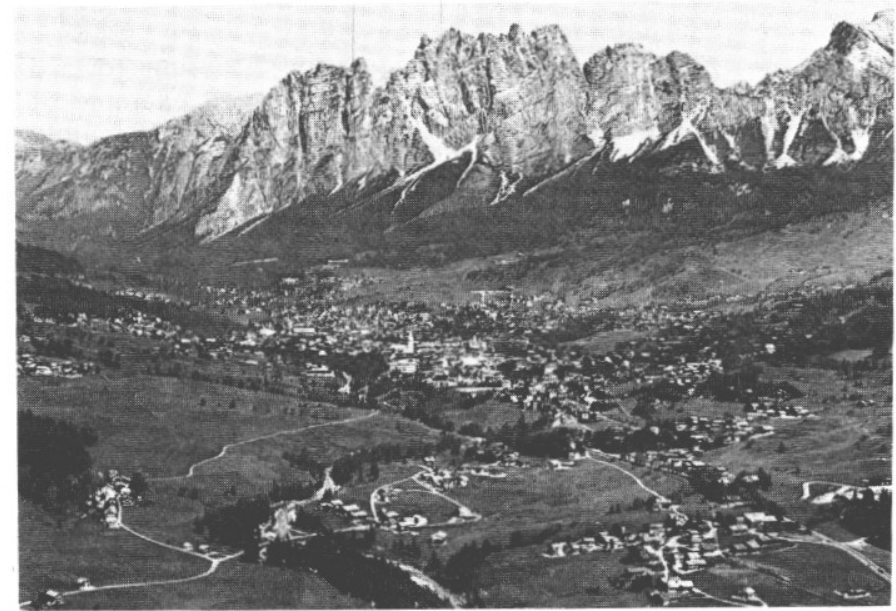

Cortina, northern Italy; the Dolomites in the background are mainly of Triassic limestone. (Photo courtesy E.T. Tozer) 
followed through the northern Appennines, Dinarides, Hellenides and Asia Minor. It is best developed in the Dinarides and Asia Minor.

In the basic-ultrabasic assemblages, there are ophiolites, which correspond to the oceanic crust of the Tethys and are generally of Jurassic age, and peridotites, which are the basal crust of continents that bordered the Tethys. Examples include the peridotites at Beni Bouchera, Morocco, and the Lanzo peridotites of northern Italy which, like the African basement that overlies them, are of Precambrian age (600 $\mathrm{Ma}$.

The line of the metamorphic suture is marked by a band of high pressure/low temperature metamorphism of blueschist facies, the first of the kind in the world to be recognized; glaucophane from the Isle of Syros was described in the last century.

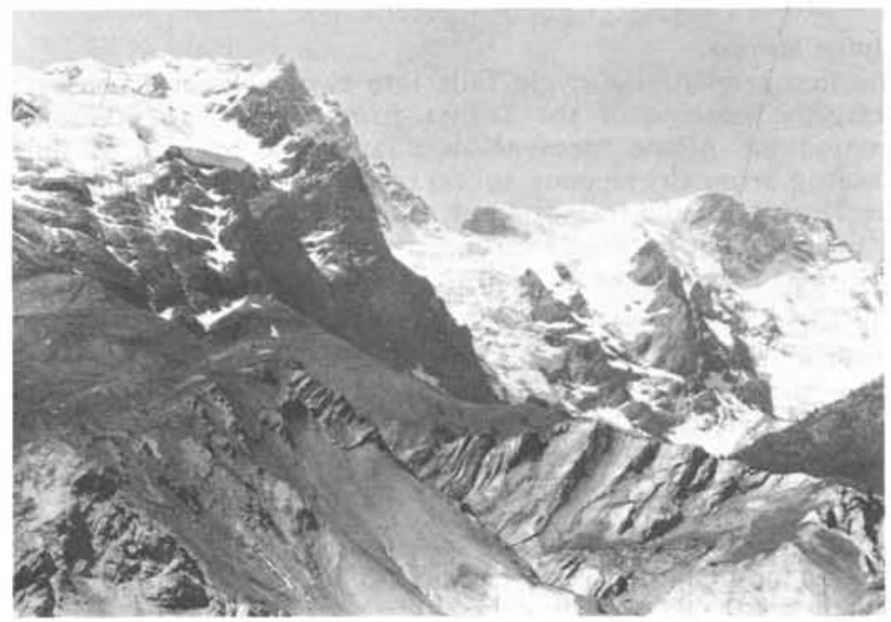

Contrasting lithologies in the French Alps: deformed phyllites of Lower Jurassic age in the foreground, with crystalline basement of the Pelvoux Massif behind; viewed from La Grave. (Photo courtesy National Museum of Wales).

The nature of the Tethyan collision was not everywhere the same: mostly it was a direct collision, giving rise only to the formation of nappes of oceanic material. In some places there was hypercollision, such as in the eastern Alps where, following closure of the Tethys, an extensive flat-lying, slicing movement thrust the Italo-Dinaric complex over the ophiolitic suture. Finally, in the few places where collision may not have occurred, there was hypocollision - in the eastern Mediterranean, for example - which explains the formation of the Tyrrhenian and Aegean arcs; here, the still active subduction is that of the remains of the Tethys whose margins have not yet been fused. For the Aegean arc, it seems that this subduction, if not completed, is on the point of being so.

Up to the Carpathians, it is basically Europe that is overthrust even if there is some counter-thrusting toward Africa (the eastern Alps offer the most striking example of this). From the Balkans and Hellenides onwards, it is mainly Africa that is overthrust, even if there is some counterthrusting toward Europe. The distribution of ophiolites, blue schists and granodiorites of Alpine age illustrates this change which, eastward from the Scutari-Pec transversal, traces the relationships that prevail from southern Eurasia to as far away as Indonesia.

Alpine chains were built up in successive stages: terminal Jurassic (Neokimmerian), middle Cretaceous (Austrian), terminal Cretaceous, terminal Eocene (Pyrenean) and intraMiocene. These stages fit into a continuous process of deformation in which they mark critical moments. The terminal Jurassic stage marks the beginning of a new phase associated with the opening of the Atlantic; the compression of the Tethys and the general appearance of flysch indicates an island-arc palaeogeography. In easternmost Europe and in northern Asia Minor, the first compressive movements date from the Triassic and Lias on the margins of Eurasia, at the same time as the Tethys was opening up elsewhere.

\section{Pyrenees-Provence Complex}

The Pyrenees-Provence complex has the character of an intercontinental chain formed between Europe and Iberia; it resembles a microplate sliding eastward along the north Pyrenean front while undergoing a southward rotation of about $35^{\circ}$. This took place in the Cretaceous and Palaeogene, and accounts for the simultaneous opening of the Bay of Biscay on the west when compressive structures were forming in the east (eastern Pyrenees, Languedoc and Provence). It may even be said that this complex sliding movement deflected the Alpine system and accentuated the curvature of the western Alps.

Thus, the north Pyrenean tront appears as a transform fault in a continental environment. Furthermore, it affected the entire lithosphere down to the deepest crust, for mafic fragments of it are squeezed in along the front in the form of Lherzolite massifs (for which the lake of Lherz in the Pyrenees is the type locality).

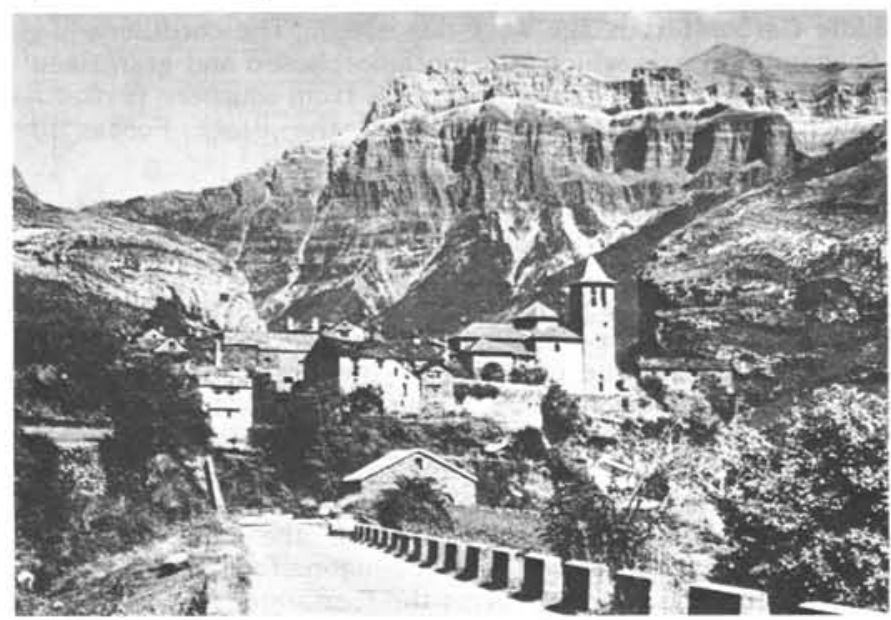

Torla fold, cored by Cretaceous strata, in the Pyrenees, Spain (looking NW). Mountains in the background are composed of Upper Cretaceous to Lower Eocene strata of the Mont Perdu Nappe overlying Paleocene rocks of the Gavarnie Nappe ("Gavarnie detachment mass"). (Photo courtesy W.C. Morgan)

It was in Provence that Marcel Bertrand (1907) first defined the concept of recumbent folds and overthrusting from studying the Beausset thrust. He compared this with the "Faille du Midi" in the Franco-Belgian coalfield and the double fold of the Glarus in the Swiss Alps, but his original interpretation still stands.

The interior seas (Mediterranean and Black Sea), formed at the expense of the Alpine chain, are associated with a postAlpine neotectonic fault field of Pliocene to Quaternary age. The boundaries of this field are oblique to the Alpine chain evident where the southern edge of the eastern Mediterranean protrudes into the Russian Platform. This Mediterranean fault field, developed at the same time as the opening of the Red Sea and the northward shift of the Arabian peninsula, extends over a complex area and appears to give it a unity that is more apparent than real. Only the western Mediterranean is truly an intramontane sea.

Ocean floors do occur in the Mediterranean:

as an inheritance trom the Mesozoic and Tertiary Tethys (the Ionian Sea, for example, and also perhaps the part of the Libyan Sea that adjoins the Aegean arc);

as a result of the Oligocene extension, which was widespread throughout western Europe and which reached the stage of an oceanic opening in the western Mediterranean: this is the origin of the Algeria-Provence basin, whose links with the fault field of central Europe are obvious; and

as a product of Pliocene and Quaternary faulting: this was 
the case with the Tyrrhenian Sea and will, in the near future, be also true for the Aegean, where neo-oceanic zones are already beginning to appear in the Gulf of Macedonia.

The Mediterranean as an entity, therefore, evolved in Pliocene to Quaternary times, following a Messinian saliferous episode that seems to have been ubiquitous. The Messinian lagoon can be sketched roughly in the outlines of the present Mediterranean, and there are increasing arguments for accepting it as a deep depression below sea level into which the sea broke suddenly during the Pliocene.

\section{Sedimentary Basins}

While Alpine history was unfolding, the Mesozoic and Tertiary sedimentary basins spread broadly across Europe, far beyond the front of the Alpine chains. They fall into two categories:

- sedimentary basins corresponding to transgressions of the Tethys or the boreal sea (and later the Atlantic) on to the European platform; and

- basins associated with the central European fault field, extending up to $300 \mathrm{~km}$ beyond the Alpine front, and breaking the substrata of the European platform up into horsts that correspond with the Hercynian massifs and graben which form so many sedimentary basins, often of narrow and elongated form.

From the Triassic to Lower Cretaceous times, transgressions moved outward from the Tethys in central and southern Europe. They are demonstrated by the closure of the basins to the west or north, where facies typical of lagoons, lakes and terrestrial environments are found (for example, in the north Pyrenean and Anglo-Paris basins).

In Upper Cretaceous times, the Atlantic opening affected most of Europe and extended to the Arctic in the Eocene. Nevertheless, there were still some basins of Tethyan affinities, such as the Castile and Ebro basins in Spain.

The principal sedimentary basins are, from south to north: the Lusitanian basin, corresponding to Portugal on the western margin of the Iberian Meseta; the New and Old Castile basins and the Ebro basin in Spain, still part of the former Tethys; the Aquitaine and Paris basins in France, whose Tethyan affinities in the Jurassic and Lower Cretaceous are succeeded by Atlantic affinities from the Upper Cretaceous onwards; and the various German basins, in which the same change took place, but only at the very end of the Cretaceous and the beginning of the Tertiary.

In northern Europe, transgressions came from a boreal sea until the opening of the Atlantic in Upper Cretaceous to Palaeogene times. But the distinction between a preAtlantic and an Atlantic history is less clear in this region because all transgressions seem to have come from the north or nor thwest.

The most important basin is that of the North Sea continental shelf, the petroleum potential of which has only recently been recognized. With its general graben form (Viking Graben, Central Graben) and thick Jurassic and Cretaceous sediments, it seems to be linked to an abortive Atlantic (or Arctic) oceanic opening in the Jurassic. This arrangement links up with the central European Graben associated with the Alpine orogeny (the Hague Graben). Thus, the North Sea basins represent a zone of interaction between the evolution of the Atlantic and that of the Alps.

In central Europe, faulting was initiated in Middle to Upper Eocene times and was fully developed in the Oligocene, following the main Alpine collision which took place in upper Eocene time. Faulting may also be related to the reaction of the European basement to this hypercollision, in the same way as the fault field of central Asia is a consequence of the hypercollision of Eurasia with the Indian continent.

The principal element in this fault field is the Rhine-Rhone axis, which cuts through Europe, across the Hercynian chain, to the front of the Alpine chain as far as the western
Mediterranean. Here it seems that the opening went so far as to detach the oceanic crust of Oligocene age, but its effects were felt to the west - in the Massif Central whose whole relief is due to these events, and in the Iberian meseta, and to the east - as far as the Harz and the Bohemian quadrilateral, whose form is that of a network of conjugate faults. The vulcanism of central Europe is associated with this fault field; its forerunners appeared in Middle Eocene and continued into late Quaternary, as in the chain of the Puys in the Massif Central.

\section{Summary}

The general framework of Europe, then, was built up progressively through successive orogenic cycles. The principal stages in these events (aside from the details of the Precambrian where the palaeogeographic picture is not yet quite clear) include: the common Palaeozoic history of North America and Europe, marking a Euramerican period which created a North Atlantic continent; the Hercynian welding of Europe and Asia creating Eurasia; the opening of the Tethys and the re-welding of Europe to Africa by the Alpine chain that is, a Eurafrican chapter.

The building of Europe did not call for progressive growth around Precambrian nuclei by the addition of successive chains. On the contrary, each chain was formed from its own oceanic opening, which was no more controlled by the preceding chain than it prepared the way for its successor. In this respect, the building of Europe is a model demonstration of the plate tectonic theory.

\section{Landscapes of Europe: Quaternary Evolution}

\section{Glacial Europe}

If the landscapes of Europe owe much to their structure (witness the contrast between Alpine peaks and Precambrian shields), many of the most obvious features are linked to very recent history and Quaternary glaciations. In fact, during successive glacial pulses, Europe was covered by three groups of glaciers (Fig. 2).

1. A vast northern icecap reached as far as London and Amsterdam and beyond Berlin, Kiev and Moscow. Centred in Scandinavia, particularly around the Baltic from where several glacial pulses pushed moraines to greater or lesser distances up to the limit noted above, this icecap was

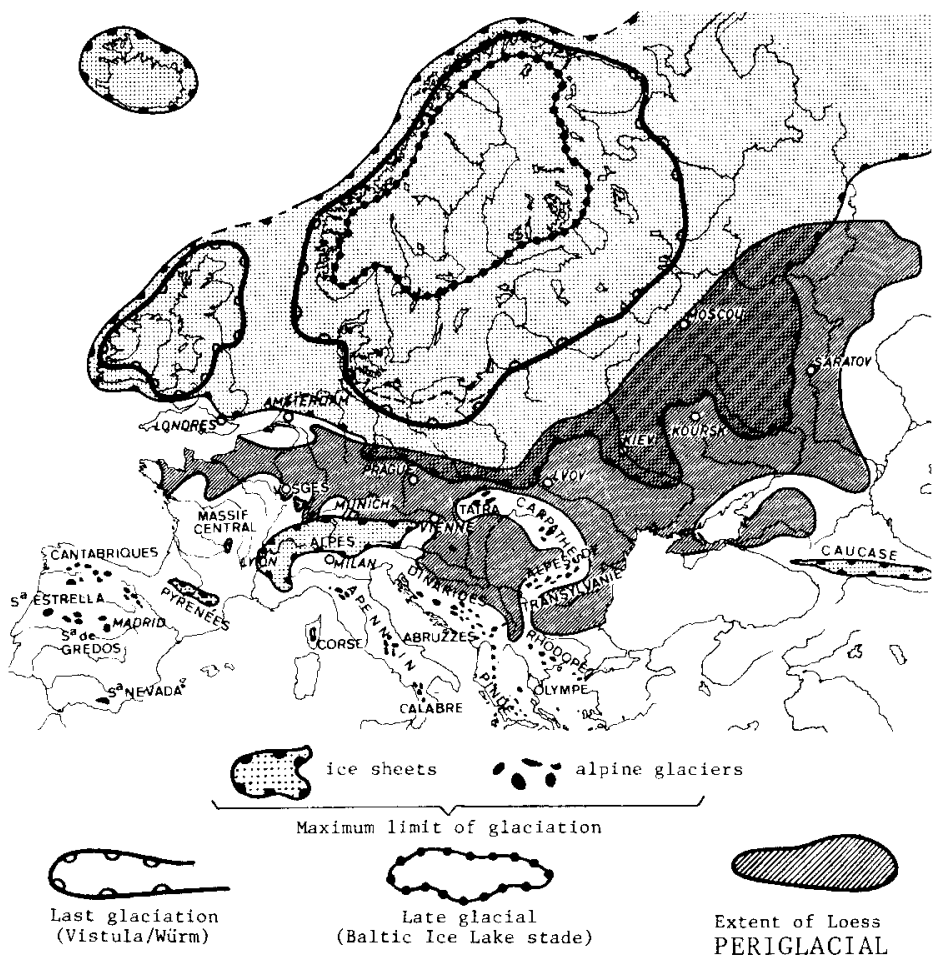

Figure 2. Outline of the Distribution of Quaternary Deposits in Europe 
reduced during the last retreat stage (termed late glacial) to a minimum before the present day retreat, with glaciers only in the high ice fields. The two main divisions within this icecovered region include the centre of the icecap, corresponding to the surroundings of the Baltic Sea (Sweden and Finland), and the area of advance and retreat of glaciers to the limits of their frontal moraines (northern Russia, Poland. northern Germanv. and the British Isles).

Two rather different types of landscape resulted:

(i) in the centre of the icecap, in areas strongly eroded by ice, the rocky substratum shows through above bottom moraines; these are landscapes with innumerable lakes;

(ii) in the advance and retreat zone, there are regions with remarkable hydrographic features: proglacial rivers running along the ice front at each retreat stage (Elbe, Oder, Vistula), whose parallelism is thereby explained; lakes are scattered here and there, although most are concentrated at the late glacial front (Vetter, Vernern, Ladoga, Onega).

2. An Alpine icecap was limited to the Alps proper. Its front extended in Bavaria as far as Munich, in France to Lyon and beyond, and in Italy almost to Milan. On a smaller scale and allowing for differences of relief, one can see here the same contrast between a high central area occupied by the icecap and areas of intermediate altitude, where glaciers advanced and retreated according to changes in climate. Similar contrasts are found between the high glacial cirques with innumerable little lakes, the glacial valleys so typical of the Alps at intermediate altitudes, and, arranged like a halo all around the Alps - the Swiss, French, Italian, Yugoslavian and Austrian lakes.

3. Some glaciations were restricted to all the high peaks of Mediterranean Europe. These were only cirque and valley glaciers, but they have given the Mediterranean mountains a morphology determined by the interplay of altitude and latitude. Even in Peloponnisos, traces of glaciation are found

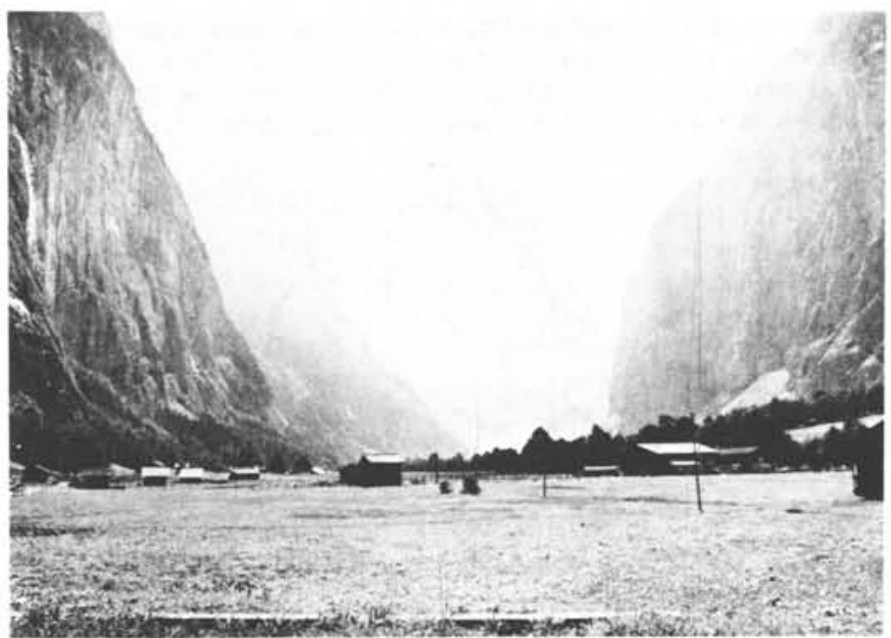

The Lauterbrunnen Valley, Switzerland, viewed to the southwest from Trummelbach. The valley shows the classic features of a glacially eroded area with steep valley sides, a flat floor and high hanging valleys. (Photo courtesy National Museum of Wales) everywhere above $2500 \mathrm{~m}$. Glaciers of the Pyrenees occupy a special place in this group, for they built up a little Pyrenean icecap on the group of peaks of the Cantal and the Mont Dore.

\section{Periglacial Europe}

Periglacial Europe extends beyond the frontal moraines. Features characterizing this region include subdued relief and presence of loess all over central Europe and in a few places in Mediterranean Europe (the Rhone valley, southern Aquitaine). Loess is widespread in Europe and unrelated to bedrock geology or tectonics. Cornice glaciers tended to carve and smooth their hosts and fill valleys with graded screes.

\section{Mediterranean Europe}

Most of Mediterranean Europe was untouched by glacial and periglacial influences except for around the edges of the high-altitude glaciers, where there is a periglacial fringe with frost-shattering of the landslips, and the like. But the glacial periods here are represented mainly by pluvial periods in the landscape, with a plant cover typical of the more northern parts of Europe today.

After the last retreat of ice, examples of this flora have been preserved in a few particular situations: an example is the forest of Sainte-Baume near Marseille which retains a northern flora at the foot of a north-facing limestone cliff, giving it a cooler microclimate.

More pronounced reliefs are typical in Mediterranean Europe: cliffs are still cliffs, often steep, especially in limestone country where the east-facing slopes' apparent immunity to erosion is the rule. By combining young reliefs with a climate well suited to their preservation, the Mediterranean is a landscape of the picturesque, heightened by the proximity of the Mediterranean Sea itself.

\section{References}

Bailey, E.B., 1928, The Palaeozoic Mountain Systems of Europe and America: Nature, v. 122, p. 811-814.

Bertrand, M., 1907, Mémoire sur les refoulements qui ont plissé l'écorce terrestre et sur le rôle des déplacements horizontaux: Mémoire, Académie des Sciences, Paris, 267 p.

Geikie, A., 1891, Anniversary address of the President: Quart. J. Geol. Soc., v. 47, p. 48-162.

Stille, H., 1924, Grundfragen der vergleichenden tektonik: Gebrüder Borntraeger, Berlin, 443 p.

Tectonic Map of Europe, 1960, Carte tectonique internationale de l'Europe: Congrès Géologique Internationale, Sous-Commission de la Carte Tectonique du Monde.

Törnebohm, A.E., 1894, Grunddragen af Sveriges geologi: P.A. Norstedt \& söners förlag, Stockholm, 213 p.

Törnquist, A.J.H., 1910, Geologie von Ostpreusser: Gebrüder Borntraeger, Berlin, 331 p.

ABOUT THE AUTHOR: Corresponding Member of the French Academy of Sciences, Head of the Geotectonics Department in the Université Pierre et Marie Curie as well as of the Laboratory of Structural Geology, which is associated with the French National Research Council (the Centre National de Recherches Scientifiques), Professor Jean Aubouin is President of the 26th International Geological Congress and Ex-officio Member of the IUGS Executive Committee (see profile in the "Meet Our Executive..." column of this issue of EPISODES).

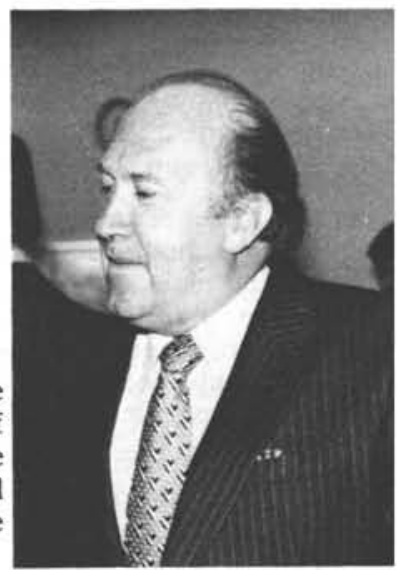

